\title{
Computerization of designing of urban transport systems using a remote satellite monitoring software product
}

\author{
$A$ Testeshev $^{1}, D$ Gense $^{1, *}, V$ Timokhovets $^{1}, T$ Babich $^{1}$, and $Y$ Chichilanova $^{1}$ \\ ${ }^{1}$ Industrial University of Tyumen, Volodarskogo str., 38, Tyumen, 625001, Russia
}

\begin{abstract}
The design of transport systems within the framework of programs for the integrated development of urban infrastructure is a cascading model that includes the stages of the analysis of target functions; monitoring of transport infrastructure; forecast transport demand; modeling of development scenarios; development, performance evaluation and verification of investment projects. To reduce resource costs, designers use a variety of hardware and software systems, the degree of security of which, their inherent advantages and disadvantages were identified during a statistical survey of employees of road facilities. According to the results of the study, to automate the collection of traffic characteristics at the monitoring stage, a software product was developed and patented to interpret a static image of a satellite image from online resources into the dynamic characteristics of traffic flows (speed, density, composition and traffic intensity). The functional apparatus of the product is the multiparameter equations of the theory of traffic flows, taking into account transport and road conditions. Assessment of the cost and capabilities of the developed software in comparison with foreign counterparts showed the vitality of this product.
\end{abstract}

\section{Introduction}

The transformation of the spatial organization of the country's economy has predetermined modern trends in socio-economic changes in cities and settlements, which are reflected in the Strategy for Spatial Development of the Russian Federation for the period until 2025 [1].

When implementing the strategy at the stage of improving the territorial organization of settlements, the design of transport infrastructure of municipal significance is carried out as part of the transport section of the master plan, territory planning projects and the development of project documentation. The initial data for project activities required traffic demand predictions, changes in the volume and nature of the movement characteristics of the road network, traffic parameters (velocity, density, intensity, and composition of movement).

Currently, these provisions are legislatively enshrined in the Decree of the Government of the Russian Federation "On approval of requirements for programs for the integrated development of the transport infrastructure of settlements, urban districts" [2].

* Corresponding author: genzeda@tyuiu.ru 
The creation of a rational transport infrastructure, including the formation of a network of streets and roads, as well as local linear objects of streets and roads, is a complex multistage activity that requires significant resources. It is possible to minimize material and time costs by computerizing the design process and using specialized software systems (SS) at as many stages of the project life cycle as possible.

The life cycle modeling of the project at the level of the master plan can be presented in the form of a cascade model, and the transport section of the master plan, territory planning projects and project documentation - according to the incremental method (figure 1).

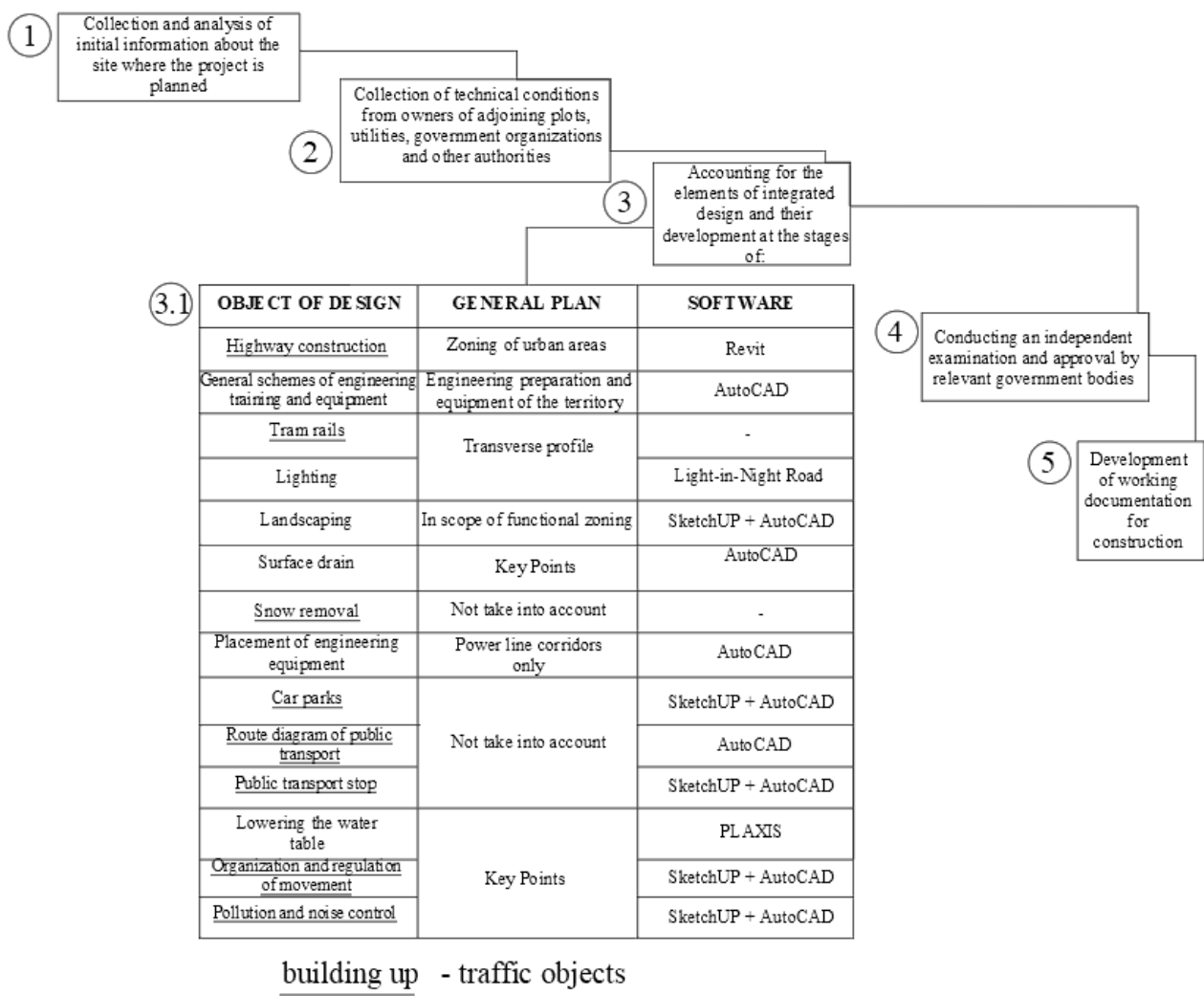

Fig. 1. Development model of the transport section of the master plan.

The analysis of the life cycle phases of scenario models showed the demand at the stage of initiation of the same set of initial data characterizing the network of streets and roads parameters and the primary parameters of traffic flows on it: traffic intensity and composition.

\section{Time spent on the preparation of the master plan}

The estimated time spent on the preparation of the master plan of the designed street and city roads was determined in accordance with $[3,4]$ and are presented in table 1 :

Table 1. Time costs for the preparation of the transport section of the master plan. 


\begin{tabular}{|c|c|c|c|}
\hline Stage name & Stage & Type of work & Time, month \\
\hline \multirow[b]{2}{*}{$\begin{array}{l}\text { Master plan of the city on a scale of } \\
\text { 1: } 5000 \text { with schemes of engineering } \\
\text { equipment and engineering } \\
\text { preparation of the territory with the } \\
\text { population }\end{array}$} & \multirow[b]{2}{*}{ - } & prospecting & $4-12$ \\
\hline & & designed & $7-18$ \\
\hline \multirow{2}{*}{$\begin{array}{l}\text { Project for a detailed layout of a } \\
\text { residential area }\end{array}$} & \multirow{2}{*}{ - } & prospecting & $3-5$ \\
\hline & & designed & $6-9$ \\
\hline \multirow{6}{*}{$\begin{array}{l}\text { Projects for the planning and } \\
\text { development of microdistricts, } \\
\text { public complexes and individual } \\
\text { plots }\end{array}$} & \multirow{3}{*}{ Design task } & complex & $2-8$ \\
\hline & & prospecting & $1-4$ \\
\hline & & designed & $1-4$ \\
\hline & \multirow{3}{*}{$\begin{array}{l}\text { Working } \\
\text { drawings }\end{array}$} & complex & $2-9$ \\
\hline & & prospecting & $1,5-6$ \\
\hline & & designed & $1,5-7$ \\
\hline
\end{tabular}

According to expert assessment, these stages, which are the basis for collecting and accumulating primary information in the form of initial data, occupy up to $50 \%$ of the project life cycle.

In modern conditions, the reduction of the complexity of the design stages is achieved through the use of software products, the demand for which in various regions of the Russian Federation and in individual enterprises is characterized by significant unevenness.

\section{Poll analysis}

To obtain the most reliable information, a selective sociological survey of design engineers of the road facilities of the Ural and Siberian Federal Districts was conducted on the subject of security with software products and software systems for the design of urban transport systems. The survey involved specialists from leading enterprises such as: «Mostostroy-11» (Tyumen), «Sverdlovskavtodor» (Ekaterinburg), «Dorspetsproekt» (Novosibirsk), etc.

At the initial stage of the questionnaire, the general population of design specialists of the road industry of the federal districts was determined, which, according to official data, amounted to 2700 people. The size of the representative sample was determined by the formula $1[5]$ :

$$
n=\frac{1}{\frac{\Delta^{2}}{t^{2} \cdot v \cdot(1-v)}+\frac{1}{N}}
$$

where $N$-total population;

$v$ - the proportion of trait $\mathrm{X}$ in the aggregate (68\% and $32 \%$ are accepted);

$t$ - factor corresponding to the confidence probability;

$\Delta-$ margin of error.

For the accepted value of the confidence probability of $5 \%$, the required number of respondents was 341 people. 
The distribution of engineering personnel by field of activity of the road industry is presented in figure 2 :
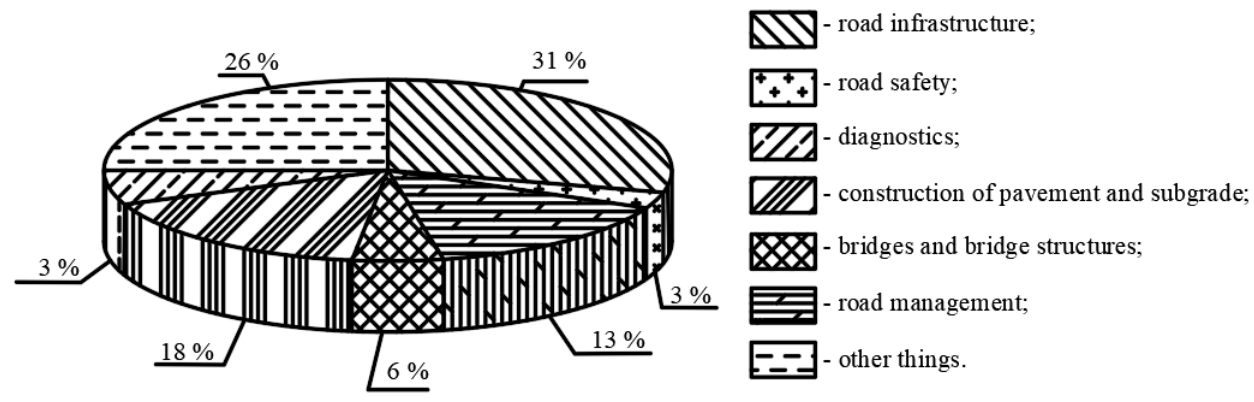

Fig. 2. Areas of activity of respondents.

According to the survey, $68 \%$ of respondents use PP in their professional activities, to one degree or another using information about the characteristics of traffic flows.

Among the shortcomings of the software products used, $56.45 \%$ of the respondents highlighted: the lack of the ability to calculate traffic flows in traffic lanes when designing a local or network transport facility (12.9\%), low power and calculation performance $(11.3 \%)$, poor functionality $(9.68 \%)$, lack of a convenient user interface $(8.06 \%)$, lack of Russian counterparts $(8.06 \%)$ and inaccessibility of software product updates $(6.45 \%)$.

Given the multifaceted nature of the research problem, an analysis was made of the functioning of the software using information about the characteristics of the traffic flow used in such a dynamically developing sphere of design and survey services as designing urban transport systems.

\section{Existing software packages}

Currently, to determine the characteristics of traffic in the practice of road construction in the Russian Federation and EU countries, the most widely used are such software systems and devices as:

1. BD “Title-2005” (LLC “Title-2005”, Russia);

2. IndorIntensity (LLC IndorSoft, Russia);

3. Golden River M660 / M680 / M720 (Schuh \& Co. GmbH, Germany);

4. IQ Central (Peek Traffic Corporation, Netherlands).

The advantages of these programs are simple and intuitive execution, user-friendly interface, a step-by-step scheme of interaction with elements of the software complex; straightforward mathematical apparatus.

The disadvantages of the considered PCs include the unintended or limited ability to take into account the parameters that affect TP; lack of variation in design scenarios; the need to teach the user the skills to work with the components and functions of the system; lack of editable databases and the ability to interact with graphic elements. Among the functional defects of these systems, one can single out the low accuracy of identification of vehicles by classification groups, the inability to control their dynamic dimensions. To crown it all, the considered software systems have a high cost, which in the conditions of limited funding makes their use not profitable. 
As a result, these shortcomings lead to the use of ineffective methods of manual accounting of traffic intensity in the search and design of urban transport systems, characterized by significant costs of financial, human and time resources.

The traditional method of direct accounting is well established in the design of local facilities, while solving the strategic tasks of planning a master plan and organizing traffic on the district network with its help is inappropriate.

Thus, the aim of this work was to develop a software product for calculating the parameters of traffic flows for planning the territorial development of urban transport schemes, which allows determining the characteristics of several transport objects at the same time, as a network construct. In addition, the objective function of software product development included the maximum reduction in the resource consumption of obtaining data on the parameters of the transport stream.

\section{Software development}

For the development of the described software under the commercial name Satellite Image, Math Plus Light Employment (SimplE), the stages were identified that were selected taking into account the requirements of Standart ISO / IEC 12207 [6,7]:

1. Analysis of the task and determination of requirements;

2. Designing a program;

3. Development, writing code;

4. Testing, debugging and quality assessment;

5. Documentation;

6. Implementation and maintenance.

The scientific basis for the development of a software product was research on the interpretation of data from remote satellite monitoring of traffic flows on street-road networks [7,9].

When analyzing the task, it was found that a necessary requirement is to consider the process of converting the static (flow density) characteristics of the transport stream into dynamic (traffic intensity), the algorithm of which is shown in figure 3.

In the typification shown in the figure, 4 main types of streets are identified: type I are transport objects with morning and evening intensity peaks, II are streets with intensity peaks in the morning, lunch and evening hours, III are streets with uniformly decreasing intensity during the day and IV - streets with a uniform distribution of intensity. 


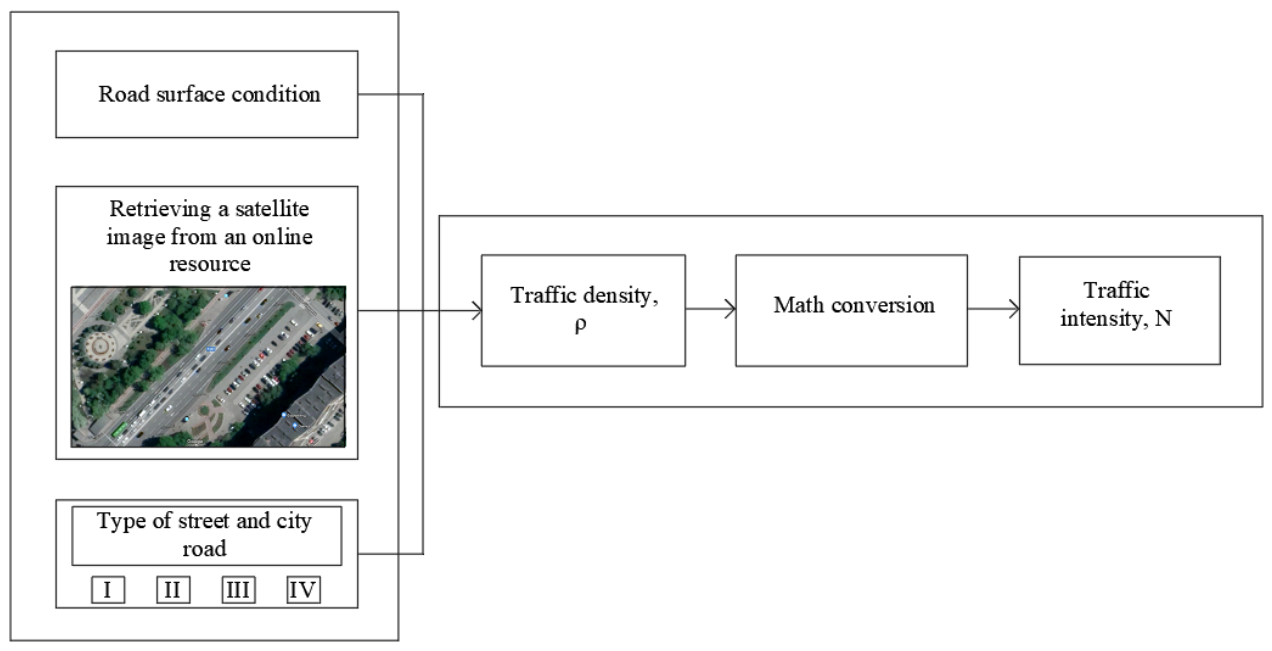

Fig. 3. Flowchart for determining the dynamic characteristics of a transport stream based on static data again.

The calculating apparatus was functional dependencies, taking into account various modes of movement and allowing to differentiate the characteristics of TP depending on transport, road and meteorological conditions [8] (form. 2-5).
a) for type 1: $N(p)=\frac{-0.0289 \times\left(S_{T}^{M} \times P_{T, R}^{M} \times \rho\right)^{2}+9.6731 \times S_{T}^{M} \times P_{T, R}^{M} \times \rho}{S_{T}^{M} \times p_{T, R}^{M}}$
b) for type $2: N(p)=\frac{-0.0285 \times\left(S_{T}^{M} \times P_{T, R}^{M} \times \rho\right)^{2}+13.316 \times S_{T}^{M} \times P_{T, R}^{M} \times \rho}{S_{T}^{M} \times p_{T, R}^{M}}$
c) for type 3: $N(p)=\frac{-0.0415 \times\left(S_{T}^{M} \times P_{T, R}^{M} \times \rho\right)^{2}+16.494 \times S_{T}^{M} \times P_{T, R}^{M} \times \rho}{S_{T}^{M} \times p_{T, R}^{M}}$
d) for type 4: $N(p)=\frac{-0.0338 \times\left(S_{T}^{M} \times P_{T, R}^{M} \times \rho\right)^{2}+11,457 \times S_{T}^{M} \times P_{T, R}^{M} \times \rho}{S_{T}^{M} \times p_{T, R}^{M}}$

$P_{T, R}^{M} \quad-$ the coefficient of bringing the estimated number of bands in one direction $P_{T, R} \quad\left(\mathrm{R}_{\mathrm{j}}\right)$, the state of the coating $\left(\mathrm{M}_{\mathrm{j}}\right)$, street type $\left(\mathrm{T}_{\mathrm{i}}\right)$ to the reference values.

$S_{T}^{M} \quad-$ the coefficient of bringing the actual state of the coating $\left(\mathrm{M}_{\mathrm{j}}\right)$, type of streets $\left(\mathrm{T}_{\mathrm{i}}\right)$ to the reference value.

Assessing the real possibilities of software and hardware, the authors proposed an automated mode of functioning of a software product associated with the visual identification of vehicles by satellite imagery and determining the characteristics of the traffic stream in automatic mode. The requirements of ISO / IEC 12207, which were taken into account when developing a new software product, are presented in figure 4 [7]: 


\begin{tabular}{|c|c|}
\hline \multirow{6}{*}{ 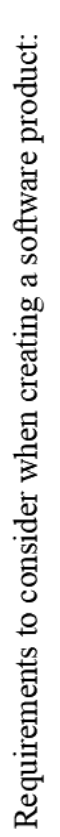 } & $\begin{array}{l}\text { the software product must be universalized and accessible for use } \\
\text { on any personal computer: desktop, laptop, ultrabook, etc. }\end{array}$ \\
\hline & $\begin{array}{l}\text { the system should be able to import and export correlated data to } \\
\text { other personal computers; }\end{array}$ \\
\hline & $\begin{array}{l}\text { in various sections of the interface of the software product (means } \\
\text { of displaying information, devices and technologies for entering } \\
\text { data, the procedure for using the program, etc.), transparent and } \\
\text { clear graphic elements of interaction with a satellite image should } \\
\text { be used; }\end{array}$ \\
\hline & $\begin{array}{l}\text { the mathematical apparatus of software must be integrated into the } \\
\text { environment and have an address database (mailing lists); }\end{array}$ \\
\hline & $\begin{array}{l}\text { standardization is necessary with the forms and pages of the } \\
\text { graphical user interface (GUI) used in basic or system personal } \\
\text { computers, as well as with personal computers of a similar } \\
\text { designation; }\end{array}$ \\
\hline & $\begin{array}{l}\text { the software product must use a mathematical apparatus that takes } \\
\text { into account a variable combination of road conditions. }\end{array}$ \\
\hline
\end{tabular}

Fig. 4. Requirements for the developed software product.

\section{Algorithm for designing a program}

When designing a software product, the following algorithm of user actions was laid down:

1. Import of satellite image from online-cartographic resource;

2. Enter the parameters of the considered section of the road network (select from the proposed city, street name, number of lanes and state of coverage, as well as the length of the section);

3. Using the icons displayed in the border of the working area, the user selects the type of vehicle and marks it with special markers on the downloaded satellite image;

4. After finishing data entry, the desired intensity value is displayed in the "Result" field on the screen, taking into account all the parameters entered into the software package.

At present, in order to automate the processes and complete the whole cycle of work related to the interpretation of the results of remote monitoring of satellite observation materials, based on the developed multiparameter equations and taking into account the above requirements, formalization of machine equation codes has been carried out.

The development of the program itself consisted in choosing a software environment and programming language. Based on the requirement that the system should be able to import and export correlated data to other software systems, the programming languages $\mathrm{C} \#$ (ECMA-334 and ISO / IEC 23270) and XAML (eXtensible Application Markup Language), which are quite universal and have an open architecture, were chosen.

The program code was written in the Microsoft Visual Studio development environment, which is shown in figure 5. 


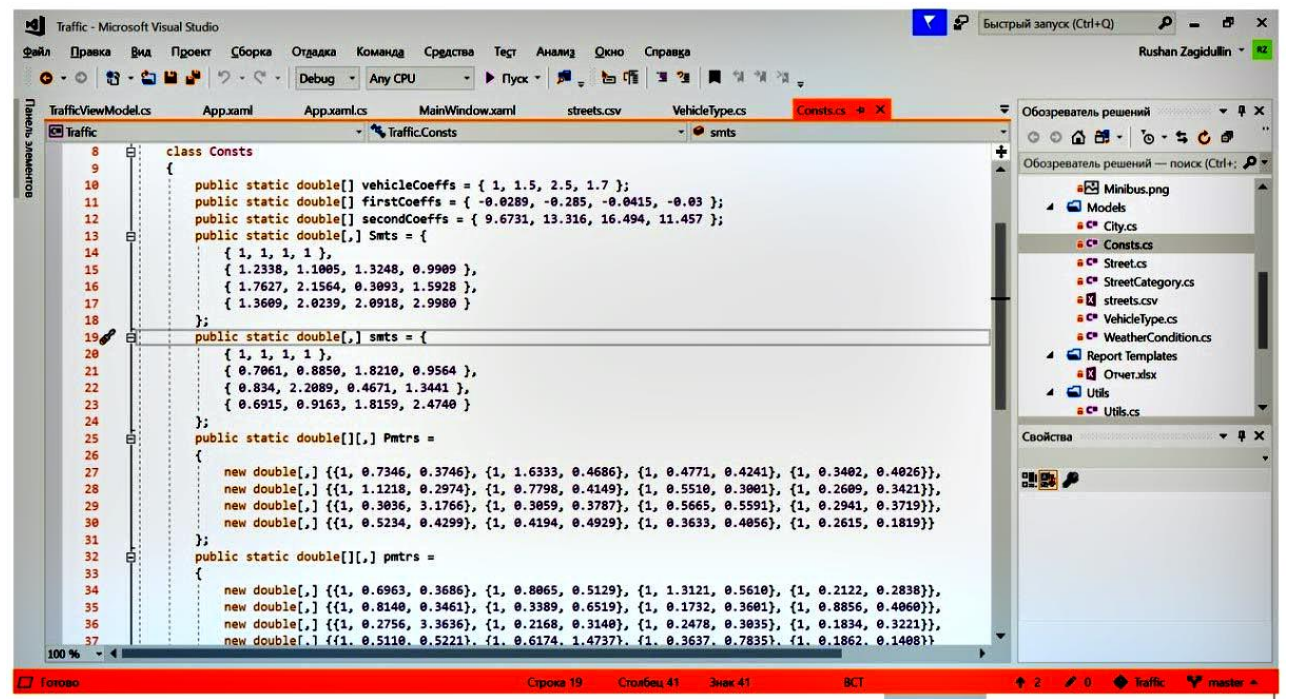

Fig. 5. Test part of the source code in the Microsoft Visual Studio software environment.

\section{Description of the working interface of the program}

Based on the requirement to use transparent graphic elements of software using the Windows Presentation Foundation (WPF) tools, a program interface was developed. The working version of the SimplE software product interface is shown in figure 6.

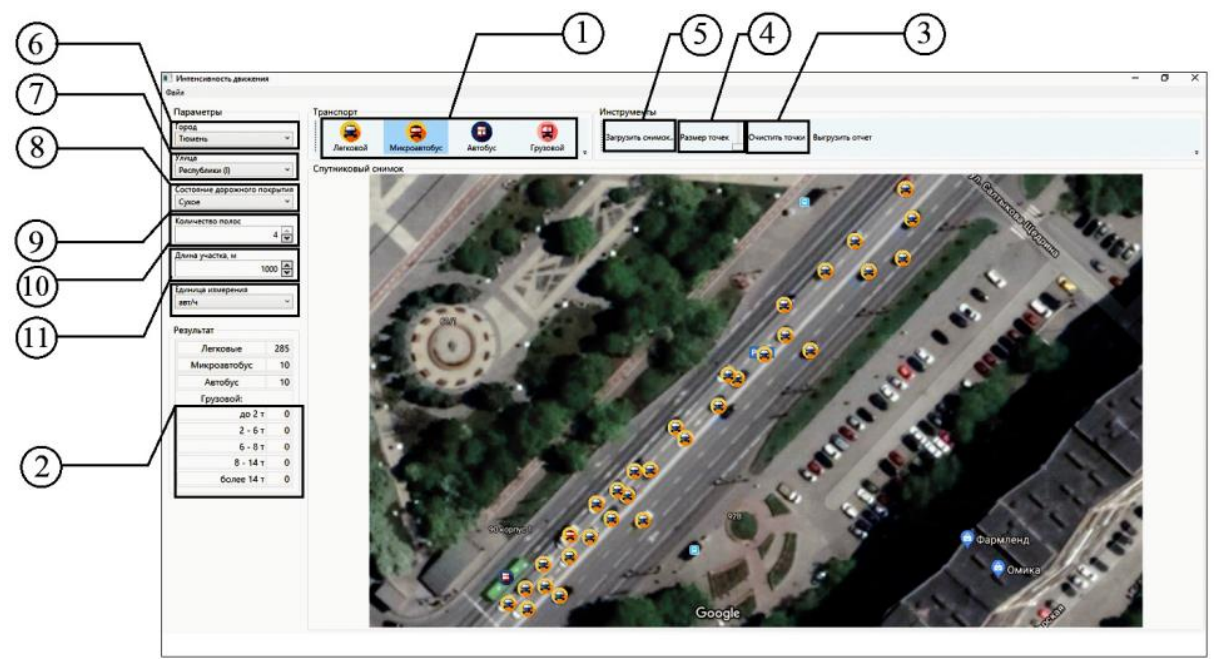

Fig. 6. Interaction with a satellite image using the SimplE software package.

The front panel integrates pictograms with a variable choice.

In the upper part are graphic elements representing the modes of transport: passenger car, truck, minibus and bus. When interacting with a truck block, a drop-down list of categories by capacity appears. 
A button for cleaning the interaction unit with a downloadable satellite image and a tool for resizing graphic elements.

In the left part of the window there is a block with drop-down lists and windows for entering numerical data.

The basic version included 17 cities, including Moscow, St. Petersburg, Yekaterinburg, Novosibirsk, Tyumen and other large and largest cities of the Russian Federation.

The streets, differentiated by types, make up the skeletal framework of the UDS (14 to 16 streets for each city). In the absence of a transport object, the user is invited to independently perform express typing according to the method:

The "state of coverage" tab allows you to choose its types: dry, wet, snow or ice.

When choosing the number of lanes, there are variability of choice from one to four lanes inclusive (9).

The length of the surveyed area is selected taking into account the off-scale magnitude of the investigated object.

The display unit of the downloaded satellite image, located under the panel of graphic elements.

Block for displaying the desired intensity value.

\section{Results and their analysis}

The beta version was tested at «Mostostroy-11» enterprises (with deviations of calculated intensity values from actual ones of $4.12 \%$ ), and quality assessment was performed at real transport facilities in Russian cities. According to the results of a comprehensive assessment, the deviations were $3.5 \%$, which is within acceptable limits, showing the performance of the proposed software and the representativeness of its results.

In terms of documenting the developed program, a patent was obtained at the Federal Service for Intellectual Property of the Russian Federation [9].

After passing through the patenting procedure, the complex was put into use by «Tyumendorproekt», «Rosdorznak» LLC and several other organizations.

At the stage of product commercialization, there was a need for an economic assessment of its cost characteristics to maintain the commercial attractiveness of software in the modern market for similar software, as well as to assess the profitability of the update performed by the results of express typing of local transport objects of a particular city.

Evaluation of the functionality of the developed program in comparison with analogues is presented in table 2:

Table 2. Comparison of the functionality of the program "SimplE" with analogues.

\begin{tabular}{|l|c|c|c|c|c|}
\hline \multicolumn{1}{|c|}{ Criterion } & $\begin{array}{c}\text { BD "Title } \\
\text { 2005" }\end{array}$ & $\begin{array}{c}\text { Golden } \\
\text { River }\end{array}$ & $\begin{array}{c}\text { IQ } \\
\text { Central }\end{array}$ & $\begin{array}{c}\text { Indor- } \\
\text { Intensit } \\
\mathbf{y}\end{array}$ & SimplE \\
\hline Usability of the interface & + & + & + & + & + \\
\hline Mobility the & - & + & - & - & + \\
\hline $\begin{array}{l}\text { Ability to identify th } \\
\text { composition of the traffic flow }\end{array}$ & + & - & + & + & + \\
\hline
\end{tabular}




\begin{tabular}{|l|l|l|l|l|l|}
\hline $\begin{array}{l}\text { Consideration of parameters } \\
\text { affecting traffic flow: }\end{array}$ & - & - & - & - & + \\
- state of coverage; & - & + & - & - & + \\
- the number of lanes; & - & - & - & - & + \\
\hline
\end{tabular}

The competitive cost of a software product, including phased programming, was determined by dependence (formula 5):

$$
\mathrm{EP}_{\Pi \Pi j}=\sum_{j=1 . .5}^{m} C H_{j} \cdot Ц_{\text {см } j},
$$

where $\mathrm{CH}_{j}$ - estimated consumption rate for the accepted meter of the $\mathrm{j}$-th type of work;

$Ц_{\text {см } j^{-}}$estimated price of the $\mathrm{j}$-th type of work:

$\mathrm{j}=1$ - layout and creation of a database by type of main motion control;

$\mathrm{j}=2$ - writing a shell;

$\mathrm{j}=3$ - integration of variable sequences of mathematical calculation;

$\mathrm{j}=4$ - creating a working interface;

$\mathrm{j}=5$ - verification and testing of a software product.

$\sum_{j=1}^{m} \quad$ - nomenclature of resources required to perform the $\mathrm{j}$-th type of work.

Following the stages of cost estimation of the developed software "SimplE", the following values can be distinguished:

Table 3. Components of the cost of software "SimplE".

\begin{tabular}{|l|c|c|c|}
\hline \multicolumn{1}{|c|}{ Index } & Rate, \$/hour & Time, hour & Total cost, \$ \\
\hline $\begin{array}{l}\text { The average salary of a software } \\
\text { engineer for creating a software } \\
\text { package in standard hours }\end{array}$ & 3.7 & 45 & 165 \\
\hline Software Product planning & 16.5 & 20 & 330 \\
\hline Program design & 16.5 & 5 & 82.5 \\
\hline Development, writing code & 31 & 12 & 370 \\
\hline Testing and debugging & 25 & 10 & 250 \\
\hline Software Support & - & - & 165 \\
\hline
\end{tabular}

The estimated cost of the software being developed (the underestimation coefficient of the software product is taken equal to 2.5) in comparison with analogues is shown in figure 7:

Thus, according to the results of assessing the intellectual value of SimplE software and its comparison with competing products, the economic efficiency of the developed software product designed for the design of urban transport systems using remote satellite monitoring data was proved 


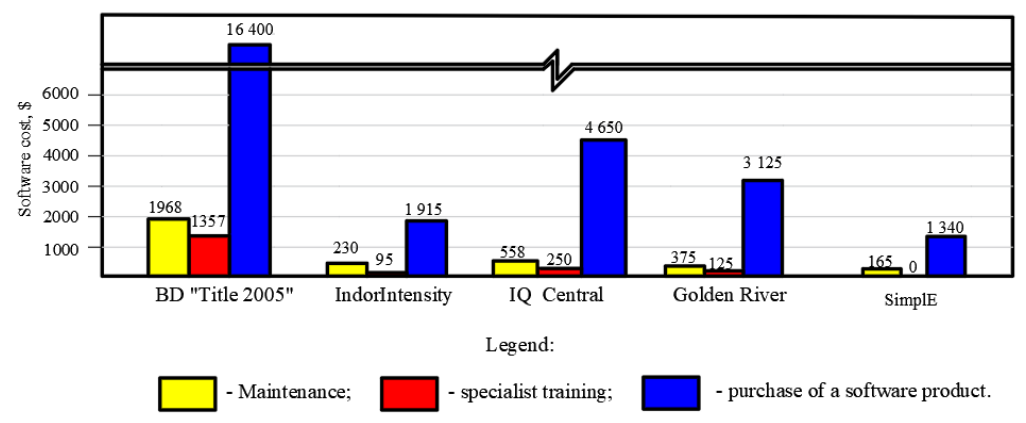

Fig. 7. Software cost estimate.

In the process of the prospective development of this scientific direction, it is planned to add to the functionality of the software product the possibility of studying transport objects with irregular traffic and expanding the database by including streets and roads, their categories.

\section{References}

1. 2019 Strategii prostranstvennogo razvitiya Rossijskoj Federacii na period do 2025 goda. Rasporyazhenie Pravitel'stva RF №207-r http://static.government.ru/media/files/UVAlqUtT08o60RktoOX122JjAe7irNxc.pdf

2. 2015 Postanovlenie Pravitel'stva RF № 1440 “Ob utverzhdenii trebovanij k programmam kompleksnogo razvitiya transportnoj infrastruktury poselenij, gorodskih okrugov" http://docs.cntd.ru/document/420327246

3. Russian Federation Standard SP 42.13330.2011 Gradostroitel'stvo. Planirovka i zastrojka gorodskih i sel'skih poselenij (Aktualizirovannaya redakciya SNiP 2.07.0189*) http://docs.cntd.ru/document/1200084712

4. Russian Federation Standard SN 283-64 «Vremennye normy prodolzhitel'nosti proektirovaniya» http://docs.cntd.ru/document/1200002043

5. Paniotto V I, Maksimenko V S 1982 Kolichestvennye metody v sociologicheskih issledovaniyah (Kiev: Naukova dumka) p 81

6. Etapy razrabotki programmnogo produkta https://mirznanii.com/a/311859/etapyrazrabotki-programmnogo-produkta/

7. IEEE/EIA Standard. Industry Implementation of International Standard ISO/IEC 12207: 1995 (ISO/IEC 12207) Standard for Information Technology - Software life cycle processes https://instruct.uwo.ca/engin-sc/se351a/readings/ISO12207_0-1996.pdf

8. Testeshev A, Timohovetz V, Mikeladze T 2018 Transportation Research Procedia 36 747

9. Testeshev A A, Timohovec V D, Sologubov A G 2019 Pat. № 2019618433 Rossijskaya Federaciya Satellite Image, Math Plus Light Employment (SimplE)

10. Testeshev A A 2018 Vestnik grazhdanskih inzhenerov 2(67) 246 